\title{
Ganglionic Cells Apoptosis in Retinal Layer of Rat Offspring due to Gestational Diabetes
}

\author{
Células Ganglionares Apoptóticas en la Capa de la Retina de \\ Crías de Ratas Debido a la Diabetes Gestacional
}

\begin{abstract}
Simin Najafdari*; Noorallah Rezaei"; Majid Malekzadeh Shafaroodi*; Soraya Ghafari** \& Mohammad Jafar Golalipour**
\end{abstract}
NAJAFDARI, S.; REZAEI, N.; SHAFAROODI, M. S.; GHAFARI, S. \& GOLALIPOUR, M. J. Ganglionic cells apoptosis in retinal layer of rat offspring due to gestational diabetes. Int. J. Morphol., 32(4):1131-1135, 2014.

SUMMARY: Previous studies have shown the adverse effects of gestational diabetes on hippocampal neuronal density in animal models. This study was conducted to determine the effect of gestational diabetes on retinal ganglionic cell density, the thickness of the retinal layer and apoptotic ganglionic cell density in 28-day-old of rat offspring. In this experimental study, 10 Wistar rat dams were randomly allocated in control and diabetic groups. Gestational diabetes was induced by $40 \mathrm{mg} / \mathrm{kg} / \mathrm{body}$ weight of streptozotocin at the first day of gestation, intraperitoneally, dams in control group received an equivalent volume normal saline. At postnatal day 28 , six offspring of each gestational diabetes and controls were randomly selected, sacrificed and sections (6 micrometer) were taken from the eye and stained with hematoxylin and eosin. The density of ganglionic cells and the number of dUTP end-labeling (TUNEL)-positive cells were evaluated in $20000 \mu \mathrm{m}^{2}$ area of ganglion layer of the retina. The ganglionic cells density were reduced (27.4\%) in gestational diabetic offspring in compared to controls $(22.5 \pm 1.5$ vs. $31.0 \pm 0.9, \mathrm{P}<0.01)$. The apoptotic ganglionic cells of retina in interventional group significantly increased in compared to controls $(6.74 \pm 0.60$ vs. $5.12 \pm 0.26, \mathrm{P}<0.02)$. This study showed that the uncontrolled gestational diabetes can reduce the number of ganglionic cells and increase apoptotic ganglionic cells of retina layer in rat offspring.

KEY WORDS: Gestational diabetes; Apoptosis; Retinal layer; Ganglionic cells; TUNEL Assay; Rat offspring.

\section{INTRODUCTION}

Diabetes mellitus is one of the most common serious metabolic disorders (Gispen \& Biessels, 2000) characterized by hyperglycemia, altered metabolism of lipids, carbohydrates and proteins (Lebed et al., 2008). Type I or insulin dependent, type II or insulin independent and gestational diabetes (GD) are three general classifications of diabetes mellitus (Persaud, 2007). Diabetes mellitus, regardless of its type, is associated with alterations in both human and animal models of the disease (Beauquis et al., 2008; Biessels et al., 1994).

Studies have shown that long lasting of gestational diabetes effects on offspring glucose homeostasis and causes increased cognitive impairment in infants of mothers with gestational hyperglycemia (Gao \& Gao, 2007).

Long-term hyperglycemia causes irreversible pathological changes in the retina and leading to an increase in diabetic retinopathy (Timmers et al., 2010). Diabetic retinopathy is a major problem in diabetics can lead to blindness (Hughes et al., 2007). Retinal ganglion cells are abundant and sizeable to study diseases of degeneration of neurons in the central nervous system (Wang et al., 2010).

Loss of thickness of retinal ganglion cells in diabetes type 1 indicates that the retinal layers are mostly influenced by the effects of diabetes (Van Dijk et al., 2010). Also, other studies have shown neuronal apoptosis and reduction of retinal ganglion cells in the early stages of diabetic retinopathy (Revsin et al., 2005; Van Dijk et al.).

Although, there are several studies regarding the adverse effects of type I and type II diabetes mellitus on retinal layer (Aizu et al., 2002; Van Dijk et al.), but there is no study about the effect of gestational diabetes on the ganglionic cell density of retinal layer in offspring. Therefore, this study was done to determine the effect of gestational diabetes on ganglionic cell density, the thickness of retina layer and apoptotic ganglion cells density in 28 postnatal days old rat offspring.

\footnotetext{
* Department of Anatomical Sciences, Mazandaran University of Medical Sciences, Sari, Iran.

** Department of Anatomical Sciences, Golestan University of Medical Sciences, Gorgan, Iran.

**** Professor, Gorgan Congenital Malformations Research Center, Department of Anatomical Sciences, Golestan University of Medical Sciences, Gorgan, Iran.
} 


\section{MATERIAL AND METHOD}

This experimental study was performed at the Gorgan Faculty of Medicine, Golestan University of Medical Sciences, Gorgan, Iran and Sari Faculty of Medicine, Mazandaran University of Medical Sciences, Sari, Iran. Guidelines on the care and use of laboratory animals and approval of the ethics committee of Golestan and Mazandaran University of Medical Sciences were obtained before study.

Experimental animals. Wistar rats, weighing 180-220 g (12 weeks old) were used. The animals were maintained in a climate-controlled room under a $12 \mathrm{~h}$ alternating light/dark cycle, $20^{\circ} \mathrm{C}$ to $22^{\circ} \mathrm{C}$ temperature, and $50 \%$ to $55 \%$ relative humidity. Dry food pellets and water were provided ad libitum.

Drug. Streptozotocin (STZ) (Sigma, St. Louis, MO, USA) dissolved in sterile saline solution $(0.85 \%)$ to give $40 \mathrm{mg} /$ $\mathrm{kg}$ dose intraperitoneally (IP) to female rats.

Animal groups and treatment. After 2 weeks of acclimation to the diet and the environment, female Wistar rats were placed with a proven breeder male overnight for breeding. Vaginal smears were done the next morning to check for the presence of sperm. Once sperm was detected that day was assigned as gestational day 1 . On day 1 of gestation, pregnant females randomly divided into two control and diabetic groups.

Five female rats in diabetic group were received 40 $\mathrm{mg} / \mathrm{kg} / \mathrm{body}$ weight of streptozotocin (STZ) (Forsberg et al., 1998) and control group (five rats) were received an equivalent volume normal saline intraperitoneally (IP).

Blood glucose measurements. Blood was sampled from the tail at 1 week after STZ injection. Blood glucose level of mothers (before mating and after STZ injection) was obtained via tail vein and was estimated with a glucometer (ACCU-CHEK ${ }^{\circledR}$ Active Glucometer, Roche Diagnostics, Mannheim, Germany) (Selvarajah \& Tesfaye, 2006).

The dams with blood glucose level 120-250 mg/dl known as gestational diabetics (Schoenle et al., 2002).

Histology. Six offspring of gestational diabetic mothers and control mothers at the day 28 were randomly selected and were killed quickly with anesthesia. For light microscope preparations eye was fixed in 10\% neutral-buffered formalin for histological procedure and after the tissue processing eyes sectioned at 6-micrometer thickness using a microtome (Microm HM 325, Germany).
Eye tissue sections were stained using hematoxylineosin. For morphometric evaluation, 10-20 sections were observed with digital light microscopy. A photograph of sections was produced using an Olympus BX51 microscope and a DP12 digital camera. The density of ganglionic cells was evaluated in $20000 \mathrm{~mm}^{2}$ area of ganglion cell layer of eye and the thickness of inner retinal layer using OLYSIA Autobioreport software.

Terminal transferased UTP nick-end labeling (TUNEL) technique. The whole-mounted retinas used for immunohistochemistry were washed extensively in PBS and tested with the terminal transferased UTP nick-end labeling (TUNEL) reaction to detect apoptosis (in situ cell death detection kit; POD; Roche, Mannheim, Germany). In the specimens used to quantitate apoptosis, the fluorescent TUNEL signal was converted to peroxidase signal and 3-3Diaminobezidine (Sigma, China) was used to visualize the reaction. The number of TUNEL- nuclei was counted in $20000 \mu \mathrm{m}^{2}$ area of ganglion cell layer of eye using OLYSIA Autobioreport software.

Statistical analysis. Statistical analysis was done by means of the statistical package SPSS 16. All data are given as mean \pm standard error of the mean (SEM). Comparisons between pairs of groups were carried out using Student's t test. Values of $\mathrm{P}<0.05$ were considered to be statistically significant.

\section{RESULTS}

Blood glucose concentrations. The mean \pm SEM of maternal blood glucose concentrations before mating and 28 days after delivery in the GD and control groups are depicted in Table I. Blood glucose levels showed a significant increase after injection of STZ in the GD group in comparison with the control group $(\mathrm{p}<0.05)$.

Table I. Maternal blood glucose level (mg/dl; Mean \pm SEM) on the insemination day and 28 day after delivery in control and streptozotocin-exposed (GD) dams.

\begin{tabular}{cccc}
\hline \multicolumn{2}{c}{ Insemination Day } & \multicolumn{2}{c}{ Day 28 } \\
Control & GD & Control & GD \\
\hline $97.7 \pm 2.3$ & $97.35 \pm 2.2$ & $97.8 \pm 2.0$ & $155.5 \pm 3.5$ \\
\hline
\end{tabular}

Morphometric results. The number of ganglion cell and the thickness of retina in postnatal day (P28) of gestational diabetic and controls offspring are depicted in Table II.

The ganglion cell density. The number of ganglion cell per $20000 \mathrm{~mm}^{2}$ area of ganglion cell layer of retina in P28were 
Table II. The number of ganglion cell, apoptotic cell and the thickness of retina in postnatal day 28 (P28) of gestational diabetes (GD) and control groups.

\begin{tabular}{|c|c|c|c|}
\hline Characteristics & Control (P28) & GD (P28) & P-value \\
\hline Ganglion cell density (GC Number $/ 20000 \mu \mathrm{m}^{2}$ area of GCL) & $31.0 \pm 0.9$ & $22.5 \pm 1.5$ & $<0.001$ \\
\hline Apoptotic cell $/ 20000 \mu \mathrm{m}^{2}$ area of GCL & $5.12 \pm 0.2$ & $6.74 \pm 0.6$ & $<0.02$ \\
\hline Thickness of retinal layer $(\mu \mathrm{m})$ & $255.3 \pm 8.2$ & $280.7 \pm 9.3$ & $<0.04$ \\
\hline
\end{tabular}

significantly reduced $(27.4 \%)$ in gestational diabetic offspring in compared controls ( $22.5 \pm 1.5$ vs. $31.0 \pm 0.9$, $\mathrm{P}<0.001)$.

Retinal layer thickness. The thickness of retinal layer significantly increased from $255.3 \pm 8.2 \mathrm{~mm}$ in the control group to $280.7 \pm 9.3 \mathrm{~mm}$ in the experimental group $(\mathrm{P}<0.04)$.

The apoptotic ganglion cell density: The number of apoptotic ganglion cell per $20000 \mu \mathrm{m}^{2}$ area of ganglion cell layer of retina in P28 were significantly increased from $5.12 \pm 0.26$ in controls to $6.74 \pm 0.60$ in gestational diabetic offsprings $(\mathrm{P}<0.02)$.

\section{DISCUSSION}

This study showed that uncontrolled gestational diabetes reduces the number of ganglionic neurons and increased the number of apoptotic ganglionic cells and retinal layer thickness of rat offspring.

Several studies have shown the effect of diabetes type I and II on retinal layer (Aizu et al.; Van Dijk et al.). Van Dijk et al., study showed that retinal ganglion cell layer thickness decreases in patients with type 1 diabetes.

Yang et al. (2012) study on five-week-old C57BL/6 mice has shown that retinal neural cell reduction occurs in induced diabetic mice by streptozotocin. It indicates that retinal neural cell loss may be an important component of diabetes.

Martin et al. (2004) study using TUNEL and activated caspase-3 methods reported that had been diabetic showed $20 \%$ to $25 \%$ fewer cells in the ganglion cell layer in mice after induction of diabetes in compared to age-matched control mice and a modest, but significant, decrease in the thickness of the whole retina and the inner and outer nuclear layers in induced- diabetic mice for 10 weeks.

Park et al. (2003) study in animal model using electron microscopy and TUNEL methods reported A few necrotic ganglion cells after 4 weeks and a slight reduction in the thickness of the inner retina and a remarkable reduction in the outer nuclear layer 24 weeks after the onset of diabetes.
Aizu et al., study on Sprague-Dawley rats one month after the onset of diabetes indicated that the thickness of the inner plexiform and photoreceptor segment layers was significantly reduced by $9.9 \%$ and $18.9 \%$, respectively (Aizu et al.). They concluded that degeneration of rods/cones in the PSL and RPE are the most prominent pathological alteration sites in the early stage of diabetic rats. In addition Mizutani et al., (1998) reported abnormalities of the b-wave of the electroretinogram in diabetic patients with absent or minimal microangiopathy have pointed to possible dysfunction of Muller cells, the principal glia of the retina.

In our study, we observed loss of ganglion cell. The data suggest that in the retina of diabetic animal, neurons in the ganglion cell layer die, and this death occurs through an apoptotic pathway (Martin et al., 2004).

Several studies have shown cell apoptosis due to diabetes (Martin et al.; Park et al.). Recent observations regarding the cellular anatomy that contributes to the bloodretinal barrier and its breakdown, reported alterations of glial cells and neurons in diabetes, and how these changes lead to loss of vision (Gardner et al., 2002).

The pathophysiologic mechanisms invoked in nonproliferative retinopathy include loss of retinal pericyte, increased retinal vascular permeability, alterations in retinal blood flow, and abnormal retinal microvasculature, which lead to retinal ischemia (Lango et al., 2012).

Also, the thickness of retinal layer may be due to inflammation reaction and increased vascular permeability in retinal vessels. The potential role of increased oxidative stress, PKC activity, and nitric oxide (NO) levels in the retina would be other logical areas to investigate as mediators of neuronal cell death in diabetic mouse retina (Martin et al.). It is also clarified that the initial phase of diabetic retinopathy is through non aminoguanidine-inhibited mechanism (Park et al.).

\section{CONCLUSION}

We concluded that the uncontrolled gestational diabetes can reduce the number of ganglionic neurons and increase apoptotic ganglionic cells of retina layer in rat offspring. 
ACKNOWLEDGEMENTS. We thank the Deputy Research of Mazandaran University of Medical Sciences, Golestan University of Medical Sciences and
Gorgan Congenital Malformations Research Center for financial support of the research (Grant number: 2345).

NAJAFDARI, S.; REZAEI, N.; SHAFAROODI, M. S.; GHAFARI, S. \& GOLALIPOUR, M. J. Células ganglionares apoptóticas en la capa de la retina de crías de ratas debido a la diabetes gestacional. Int. J. Morphol., 32(4):1131-1135, 2014.

RESUMEN: Estudios previos en un modelo animal han demostrado los efectos adversos de la diabetes gestacional en la densidad neuronal del hipocampo. El objetivo fue determinar el efecto de la diabetes gestacional en la densidad de las células ganglionares de la retina, en el espesor de la capa de la retina y en la densidad de las células apoptóticas ganglionares, en crías de ratas de 28 días. En este estudio experimental, 10 ratas Wistar fueron asignadas aleatoriamente en grupos control y diabéticos. La diabetes gestacional se indujo a partir de la administración de $40 \mathrm{mg} / \mathrm{kg} /$ peso corporal de estreptozotocina en el primer día de la gestación, por vía intraperitoneal. Al grupo control se administró un volumen equivalente de solución salina normal. En el día 28 luego del nacimiento, se seleccionaron aleatoriamente seis crías procedentes de los grupos con diabetes gestacional y controles, se eutanasiaron y se tomaron muestras de los ojos, en forma de secciones de 6 micrómetros, las cuales se tiñeron con H \& E. La densidad de las células ganglionares y el número final de células dUTP positivas (TUNEL) se evaluaron a nivel de la capa ganglionar de la retina, en un área de $20.000 \mathrm{~mm}^{2}$. La densidad de las células ganglionares se redujo un $27,4 \%$ en la descendencia con diabetes gestacional en comparación con los controles (22,5 $\pm 1,5$ vs. $31,0 \pm 0,9, \mathrm{P}<0,01)$. Las células ganglionares apoptóticas de la retina en el grupo con diabetes gestacional aumentaron significativamente en comparación con los controles $(6,74 \pm 0,60$ vs. $5,12 \pm 0,26, \mathrm{P}<0,02)$. Este estudio demostró que la diabetes gestacional no controlada puede reducir el número de células ganglionares y aumentar el número de células ganglionares apoptóticas de la capa de la retina en las crías de las ratas con diabetes gestacional.

PALABRAS CLAVE: Diabetes gestacional; Apoptosis; Capa de la retina; Células ganglionares; TUNEL ensayo; Crías de ratas.

\section{REFERENCES}

Aizu, Y.; Oyanagi, K.; Hu, J. \& Nakagawa, H. Degeneration of retinal neuronal processes and pigment epithelium in the early stage of the streptozotocin-diabetic rats. Neuropathology, 22(3):161-70, 2002.

Beauquis, J.; Saravia, F.; Coulaud, J.; Roig, P.; Dardenne, M.; Homo-Delarche, F. \& De Nicola, A. Prominently decreased hippocampal neurogenesis in a spontaneous model of type 1 diabetes, the nonobese diabetic mouse. Exp. Neurol., 210(2):359-67, 2008.

Biessels, G. J.; Kappelle, A. C.; Bravenboer, B.; Erkelens, D. W. \& Gispen, W. H. Cerebral function in diabetes mellitus. Diabetologia, 37(7):643-50,1994.

Forsberg, H.; Eriksson, U. J. \& Welsh, N. Apoptosis in embryos of diabetic rats. Pharmacol. Toxicol., 83(3):104-11,1998.

Gao, Q. \& Gao, Y. M. Hyperglycemic condition disturbs the proliferation and cell death of neural progenitors in mouse embryonic spinal cord. Int. J. Dev. Neurosci., 25(6):349-57, 2007.

Gardner, T. W.; Antonetti, D. A.; Barber, A. J.; LaNoue, K. F.; Levinson, S. W. Diabetic retinopathy: more than meets the eye. Surv. Ophthalmol., 47(Suppl. 2):S253-62, 2002.

Gispen, W. H. \& Biessels, G. J. Cognition and synaptic plasticity in diabetes mellitus. Trends Neurosci., 23(11):542-9, 2000.
Hughes, J. M.; Kuiper, E. J.; Klaassen, I.; Canning, P.; Stitt, A. W.; Van Bezu, J.; Schalkwijk, C. G.; Van Noorden, C. J. \& Schlingemann, R. O. Advanced glycation end products cause increased CCN family and extracellular matrix gene expression in the diabetic rodent retina. Diabetologia, 50(5):1089-98, 2007.

Lebed, Y. V.; Orlovsky, M. A.; Nikonenko, A. G.; Ushakova, G. A. \& Skibo, G. G. Early reaction of astroglial cells in rat hippocampus to streptozotocin-induced diabetes. Neurosci. Lett., 444(2):181-5, 2008.

Longo, D.; Fauci, A.; Kasper, D.; Hauser, S.; Jameson, J. \& Loscalzo, J. Harrison's Principles of Internal Medicine. $18^{\text {th }}$ ed. New York, Mc Graw-Hill, 2012.

Martin, P. M.; Roon, P.; Van Ells, T. K.; Ganapathy, V. \& Smith, S. B. Death of retinal neurons in streptozotocin-induced diabetic mice. Invest. Ophthalmol. Vis. Sci., 45(9):3330-6, 2004.

Mizutani, M.; Gerhardinger, C. \& Lorenzi, M. Müller cell changes in human diabetic retinopathy. Diabetes, 47(3):445-9, 1998.

Park, S. H.; Park, J. W.; Park, S. J.; Kim, K. Y.; Chung, J. W.; Chun, M. H. \& Oh, S. J. Apoptotic death of photoreceptors in the streptozotocin-induced diabetic rat retina. Diabetologia, 46(9):1260-8, 2003.

Persaud, O. D. D. Maternal diabetes and the consequences for her offspring. J. Dev. Disabil., 13(1):101-34, 2007. 
NAJAFDARI, S.; REZAEI, N.; SHAFAROODI, M. S.; GHAFARI, S. \& GOLALIPOUR, M. J. Ganglionic cells apoptosis in retinal layer of rat offspring due to gestational diabetes. Int. J. Morphol., 32(4):1131-1135, 2014

Revsin, Y.; Saravia, F.; Roig, P.; Lima, A.; de Kloet, E. R.; HomoDelarche, F. \& De Nicola, A. F. Neuronal and asteroglial alteration in the hippocampus of a mouse model for type 1 diabetes. Brain Res., 1038(1):22-31, 2005.

Schoenle, E. J.; Schoenle, D.; Molinari, L. \& Largo, R. H. Impaired intellectual development in children with Type I diabetes: association with $\mathrm{HbA}(1 \mathrm{c})$, age at diagnosis and sex. Diabetologia, 45(1):108-14, 2002.

Selvarajah, D. \& Tesfaye, S. Central nervous system involvement in diabetes mellitus. Curr. Diab. Rep., 6(6):431-8, 2006.

Timmers, A. M.; Miller, C. M. \& Zhu, L. Animal models of diabetic retinopathy. In: Pang, I-H.; Clark, A. F. (Eds.). Animal Models for Retinal Diseases, Series Neuromethods, Vol. 46. United States, Humana Press, 2010.

van Dijk, H. W.; Verbraak, F. D.; Kok, P. H.; Garvin, M. K.; Sonka, M.; Lee, K.; Devries, J. H.; Michels, R. P.; van Velthoven, M. E.; Schlingemann, R. O. \& Abràmoff, M. D. Decreased retinal ganglion cell layer thickness in patients with type 1 diabetes. Invest. Ophthalmol. Vis. Sci., 51(7):3660-5, 2010.

Wang, X.; Teng, L.; Li, A.; Ge, J.; Laties, A. M. \& Zhang, X. TRPC6 channel protects retinal ganglion cells in a rat model of retinal ischemia/reperfusion-induced cell death. Invest. Ophthalmol. Vis. Sci., 51(11):5751-8, 2010.

Yang, Y.; Mao, D.; Chen, X.; Zhao, L.; Tian , Q.; Liu, C. \& Zhou, B. L. Decrease in retinal neuronal cells in streptozotocininduced diabetic mice. Mol. Vis., 18:1411-20, 2012.

\author{
Correspondence to: \\ Mohammad Jafar Golalipour \\ Gorgan Congenital Malformations Research Center \\ Department of Anatomical Sciences \\ Golestan University of Medical Sciences \\ Gorgan \\ IRAN
}

Email: mjgolalipour@yahoo.com

Received: 08-05-2014

Accepted: 22-07-2014 